\title{
Hubungan Staging Kanker Paru dengan Skala Nyeri pada Pasien Kanker Paru yang Dirawat di Bagian Paru RSUP DR M Djamil Padang
}

Rian Rizki Ananda ${ }^{1}$, Sabrina Ermayanti ${ }^{2}$, Abdiana $^{3}$

\begin{abstract}
Abstrak
Pasien kanker paru banyak ditemukan sudah berada pada stadium lanjut. Nyeri banyak dikeluhkan oleh pasien kanker paru. Nyeri yang dialami oleh pasien dapat menurunkan kualitas hidup pasien. Tujuan penelitian ini adalah menentukan hubungan stadium kanker paru dan skala nyeri pada pasien kanker paru yang dirawat di Bagian Paru RSUP Dr M Djamil Padang. Penelitian ini merupakan studi observasi analitik dengan desain potong lintang. Sampel penelitian ini adalah data rekam medik pasien kanker paru di Bagian Paru RSUP DR. M Djamil Padang periode tahun 2014 sampai 2015 yang berjumlah 66 pasien. Penelitian dilakukan pada bulan Oktober 2017 sampai Maret 2018 di RSUP Dr M Djamil Padang. Data dianalisis menggunakan uji Chi-square. Hasil studi didapatkan karakteristik pasien kanker paru terbanyak adalah umur $>40$ tahun $(90,9 \%)$, jenis kelamin laki-laki $(84,8 \%)$, status rokok adalah sebagai perokok (74,2\%), dan jenis sel Kanker Paru Jenis Karsinoma Bukan Sel KeciL/KPKBSK (45,5\%). Pasien paling banyak berada pada stadium lanjut (93,9\%) dengan keluhan nyeri paling banyak adalah nyeri sedang (51,5\%). Berdasarkan hasil penelitian disimpulkan tidak ada hubungan yang bermakna antara staging kanker paru dengan skala nyeri.
\end{abstract}

Kata kunci: kanker paru, stadium, nyeri

\section{Abstract}

Lung cancer patients are found to be at an advanced stage. Pain is often complained by lung cancer patients. Pain experienced by the patient can decrease the quality of life of the patient. The objective of this study was to determine the correlation between lung cancer staging and pain scale in lung cancer patients that treated in the lung Department of RSUP Dr M Djamil Padang. This research was an analytical observation research with cross sectional design. The samples of this study were lung cancer patients who have medical record in The Lung Department of RSUP Dr M Djamil Padang in 2014 until 2015 which amounted to 66 patients. The study was conducted from October 2017 to March 2018 at RSUP DR M Djamil Padang. The data was analyzed by Chi-square test. The results showed that most of lung cancer patients were $>40$ years old (90,9\%), male (84,8\%), smoker (74,2\%), and Non small cell lung cancer (57,6\%). The most patients were in advanced stage (93,9\%) with most pain complaint was moderate pain (51,5\%). This research concludes no significant correlation between lung cancer staging and pain scale.

Keyword: lung cancer, stage, pain

\footnotetext{
Affiliasi penulis: 1. Prodi Kedokteran Fakultas Kedokteran Universitas Andalas Padang (FK Unand), 2. Bagian Paru FK Unand, 3. Bagian IImu Kesehatan Masyarakat FK Unand Korespondensi: Rlan Rizki Ananda, Email: rian30ananda@gmail.com Telp: 081270124252
}

\author{
PENDAHULUAN \\ Kanker paru masih menjadi penyebab \\ terbanyak kematian akibat kanker. Angka kejadian \\ kanker paru di dunia mencapai $13 \%$ dari semua \\ kanker didunia selama tahun $2012{ }^{1}$
}


Angka ketahanan hidup 5 tahun secara keseluruhan masih mengecewakan, yaitu $15 \%$. Salah satu penyebab rendahnya angka ketahanan hidup dikarenakan rendahnya kesadaran masyarakat untuk melakukan pemeriksaan dini terhadap kanker paru. ${ }^{2}$ Angka kejadian kanker paru pada pria mencakup 14\% dari keseluruhan jenis kanker yang diteliti dan pada wanita mencakup $13 \%{ }^{3}$

Kejadian kanker paru di Indonesia belum ada data pasti. Data yang tersedia baru berupa laporan dari beberapa rumah sakit. Data dari rumah sakit Kanker Dharmais Jakarta tahun 2013, didapat 173 kaus kanker paru $(7,7 \%$ dari keseluruhan jenis kanker). Data di rumah sakit Dr. M.Djamil Padang periode tahun 2004-2013 didapat 275 kasus kanker paru yang sudah diketahui jenis selnya. ${ }^{4}$

Pasien kanker paru banyak didiagnosis pada stage lanjut (stage III dan IV). Pasien yang ditemukan pada stage ini cenderung memiliki banyak keluhan dan komplikasi akibat kanker yang dialaminya. Keluhan ini disebabkan oleh gangguan yang diakibatkan oleh sel kanker tersebut kedaerah sekitar, maupun akibat dari metastasis sel tersebut ke bagian tubuh lainnya (65\% kasus). ${ }^{5}$

Keluhan yang ditemukan pada pasian kanker paru dapat berupa batuk, nafas pendek, nyeri dada, batuk darah, mual, nyeri, kelelahan dan beberapa keluhan lainnya. Nyeri adalah keluhan utama yang sering dikeluhkan. Penelitian yang membandingkan antara kanker paru dan penyakit kronik paru lainnya, diadapatkan data bahwa rasa nyeri lebih banyak dirasakan oleh pasien dengan kanker paru (62\%). ${ }^{6}$

Metastasis kanker paru ke tulang menyebabkan keluhan nyeri yang dirasakan oleh sekitar $25 \%$ pasien. Keluhan nyeri ini dapat menyebabkan turunnya kualitas hidup yang dirasakan oleh pasien. Metastasis kanker ke tulang lengan dan kaki, menyebabkan keluhan nyeri lebih berat pada saat adanya gerakan. Ketika metastasis sampai ke tulang belakang, nyeri lebih dirasakan pada malam hari dan setelah beristirahat di tempat tidur. ${ }^{7}$

Keluhan nyeri lebih banyak ditemukan pada pasien dengan kanker paru stage lanjut (stage III dan IV). Keluhan nyeri ini juga menyebabkan turunnya kualitas hidup yang dirasakan penderita kanker paru. ${ }^{8}$
Penelitian pada pasien kanker paru stadium III (29\%) dan IV (71\%) menemukan bahwa pasien kanker paru yang sudah mendapatkan perawatan seperti kemoterapi selama 90 hari tetap merasakan nyeri yang berat, meskipun telah diberikan analgesik. ${ }^{9}$

Berdasarkan hal diatas, maka perlu dilakukan penelitian tentang hubungan staging kanker paru dengan skala nyeri pada penderita kanker paru. Penelitian ini dilakukan di RSUP M.Djamil Padang, karena RSUP M.Djamil Padang menjadi tempat rujukan utama pasien kanker paru untuk wilayah Sumatera Barat

\section{METODE}

Penelitian ini merupakan studi analitik dengan design cross sectional. Penelitian dilakukan di Bagian Paru RSUP DR. M Djamil Padang pada bulan Oktober 2017 sampai Maret 2018. Penelitian ini menggunakan data sekunder yang berasal dari status penderita yang masuk ke Bagian Paru RSUP DR. M Djamil Padang mulai tahun 2014 sampai 2015. Sampel penelitian ini adalah pasien kanker paru yang memiliki data rekam medis di Bagian Paru RSUP DR. M Djamil Padang dari tahun 2014 sampai 2015. Hasil penelitian dianalisis dengan menggunakan uji statistik Chi-square.

\section{HASIL}

Tabel 1. Distribusi frekuensi karakteristik pasien kanker paru

\begin{tabular}{|c|c|c|}
\hline Karakteristik & Frekuensi & $\%$ \\
\hline Umur & 6 & 9,1 \\
\hline - $\leq 40$ tahun & 60 & 90,9 \\
\hline \multicolumn{3}{|l|}{ - $>40$ tahun } \\
\hline \\
\hline \multicolumn{3}{|l|}{ Jenis Kelamin } \\
\hline - Laki-laki & 56 & 84,8 \\
\hline - Perempuan & 10 & 15,2 \\
\hline \multicolumn{3}{|l|}{ Status Rokok } \\
\hline - Bukan Perokok & 13 & 19,7 \\
\hline - Perokok & 49 & 74,2 \\
\hline - Bekas Perokok & 4 & 6,1 \\
\hline \multicolumn{3}{|l|}{ Jenis Sel } \\
\hline - Sel Skumosa & 12 & 18,2 \\
\hline - Adenokarsinoma & 22 & 33,3 \\
\hline - Sel Besar & 0 & 0 \\
\hline • KPKSK & 1 & 1,5 \\
\hline - KPKBSK & 30 & 45,5 \\
\hline - Campuran & 1 & 1,5 \\
\hline
\end{tabular}


Tabel 1 menunjukkan karakteristik pasien kanker paru paling banyak pada umur $>40$ tahun $(90,9 \%)$, jenis kelamin laki-laki $(84,8 \%)$, status rokok adalah sebagai perokok $(74,2 \%)$, dan jenis sel KPKBSK (45,5\%)

Tabel 2. Distribusi frekuensi stage kanker paru

\begin{tabular}{lcc}
\hline Stage Kanker & Frekuensi & $\%$ \\
\hline Stage Awal & 4 & 6,1 \\
Stage Lanjut & 62 & 93,9 \\
Total & 66 & 100
\end{tabular}

Penilaian staging kanker dilakukan melalui rekam medik pasien. Stage kanker pada pasien ditentukan berdasarkan Penderajatan Internasional Kanker Paru Versi 7 tahun 2007.

Tabel 2 menunjukkan pasien kanker paru yang dirawat di bangsal paru periode 2014-2015 paling banyak berada pada stage lanjut 93,9\%.

Skala nyeri pasien dilihat pada data VAS pasien yang terdapat didalam rekam medik pasien. Penggunaan VAS biasanya dilakukan oleh petugas kesehatan dengan melihat dan menilai ekspresi wajah pasien lalu dituliskan dalam skala 1-10.

Tabel 3. Distribusi frekuensi skala nyeri pasien kanker paru

\begin{tabular}{lcc}
\hline Skala Nyeri & Frekuensi & $\%$ \\
\hline Ringan & 19 & 28,8 \\
Sedang & 34 & 51,5 \\
Berat & 13 & 19,7 \\
Total & 66 & 100 \\
\hline
\end{tabular}

Tabel 3 menunjukkan nyeri terbanyak yang dirasakan oleh pasien adalah nyeri sedang (51,5\%).

Pada masing-masing data rekam medik pasien telah tercantum stage kanker yang dialami dan berapa skala nyeri yang dirasakannya. Data dari stage kanker dan skala nyeri diolah sehingga didapatkan hubugan diantara kedua data.

Tabel 4 menunjukkan pasien kanker paru stage lanjut paling banyak mengeluhkan nyeri sedang yaitu $53,2 \%$ dan pada stage awal yang paling banyak dikeluhkan adalah nyeri ringan yaitu $50 \%$. Hasil uji statistik menunjukkan nilai $p$ sebesar 0,52 yang artinya tidak ada hubungan bermakna antara staging kanker paru dengan skala nyeri
Tabel 4. Hubungan stage kanker paru dengan skala nyeri pasien kanker paru di Bagian Paru RSUP Dr. M. Djamil Padang tahun 2014-2015

\begin{tabular}{lcccc}
\hline \multirow{2}{*}{$\begin{array}{c}\text { Staging } \\
\text { kanker }\end{array}$} & \multicolumn{3}{c}{ Skala nyeri } & \multirow{2}{*}{ p } \\
\cline { 2 - 4 } & Ringan & Sedang & Berat & \\
\hline Stage & 2 & 1 & 1 & \\
awal & $(50 \%)$ & $(25 \%)$ & $(25 \%)$ & \\
Stage & 17 & 33 & 12 & 0,52 \\
lanjut & $(27,4 \%)$ & $(53,2 \%)$ & $(19,4 \%)$ & \\
& & & & \\
\hline
\end{tabular}

\section{PEMBAHASAN}

\section{Karakteristik Pasien Kanker Paru}

Pada hasil penelitian didapatkan bahwa usia terbanyak berada diatas 40 tahun (90,9\%). Penderita kanker paru lebih banyak ditemukan pada usia diatas 40 tahun disebabkan pajanan zat yang bersifat karsinogenik secara berkepanjangan. Zat karsinogenik dapat berasal dari lingkungan kerja maupun rumah. Efek zat karsinogenik muncul setelah beberapa tahun dan resiko terbesar mulai pada usia 40 tahun. ${ }^{10,11}$

Pasien kanker paru terbanyak pada penelitian ini adalah laki-laki (84,8\%). Kanker paru lebih banyak ditemukan pada jenis kelamin laki-laki karena kebiasaan merokok yang lebih sering daripada perempuan dan laki-laki mempunyai mobilitas tinggi sehingga lebih banyak terpapar bahan karsinogenik seperti asap rokok, bahan industri di lingkungan kerja, maupun polusi udara. ${ }^{10,11}$

Pada penelitian ini didapatkan data bahwa pasien kanker paru terbanyak adalah perokok (74,2\%). Paparan oleh polusi udara dan berbagai zat karsinogenik bisa saja sama-sama dialami oleh perokok, bekas perokok dan bukan perokok. Namun dari segi konsumsi rokok, perokok lebih sering terpapar oleh asap rokok yang ia konsumsi. Maka dari itu perokok aktif memiliki kemungkinan terbesar untuk menderita kanker paru dibandingkan dengan bukan perokok dan bekas perokok. ${ }^{12,13}$

Jenis sel kanker yang banyak ditemui adalah jenis adenokarsinoma 33,3\% dan Kanker Paru Jenis Karsinoma Bukan Sel KeciL (KPKBSK) sebanyak 45,5\%. Dilihat dari sejarahnya, rokok pertama didunia dibuat menggunakan tembakau yang dibungkus dengan daun tembakau itu sendiri, kertas, daun jagung, atau daun aren. Rokok yang digunakan 
dengan membungkus tembakau ini dikenal dengan sebutan rokok putih. Pada mula masuknya bangsa Eropa ke Indonesia, mereka mempekenalkan tembakau sebagai bahan pembuatan rokok. Di Indonesia rokok dibuat tidak hanya menggunakan tembakau, namun juga dicampurkan dengan cengkeh dan ada juga yang ditambahkan dengan kemenyan. Rokok-rokok ini dibakar dan dihisap secara mendalam untuk memenuhi kepuasan akan nikotin yang terdapat didalam tembakau. Penghisapan dalam menyebabkan zat-zat hasil pembakaran masuk ke dalam saluran nafas besar (trakea), sehingga banyak ditemukannya kanker paru karsinoma tipe skuamosa. Pada perkembangan selanjutnya, ditemukan rokok yang menggunakan filter. Rokok yang menggunakan filter menyaring zat-zat hasil pembakaran menjadi lebih halus, sehingga zat-zat tersebut dapat mencapai perifer bronkus dan menyebabkan munculnya sel kanker karsinoma tipe adenokarsinoma. ${ }^{14,15}$

\section{Stage Kanker}

Berdasarkan hasil didapatkan pasien kanker paru terbanyak adalah pasien dengan stage lanjut (93,9\%). Banyak faktor yang menyebabkan banyaknya pasien kanker paru pada stage lanjut. Gejala kanker paru yang tidak khas pada awal terbentuknya kanker bisa menjadi salah satu diantaranya. Gejala yang dialami pada awal kanker seperti kelelahan, nafsu makan yang menurun, batuk berkepanjangan, dan nyeri di dada saat batuk sering dianggap sebagai penyakit ringan oleh pasien. Kebanyakan tidak melakukan pemeriksaan kesehatan terhadap penyakitnya. Ketika kondisi sudah memburuk dan kanker sudah berada pada stage lanjut, maka pasien memeriksakan diri ke dokter. ${ }^{13}$

Selain tidak khasnya gejala yang dirasakan, kesadaran diri pasien untuk melakukan pemeriksaan berkala masih rendah. Banyak pasien dengan resiko tinggi terkena kanker paru yang tidak melakukan pemeriksaan berkala. Banyak alasan yang diungkapkan seperti kesibukan, besarnya biaya pengobatan dan ketakutan terhadap hasil pemeriksaan membuat pasien enggan untuk melakukan pemeriksaan. $^{2}$
Kesalahan dari tenaga medis juga dapat menyebabkan banyaknya kanker paru ditemukan pada stage lanjut. Kesalahan diagnosa pada pasien menyebabkan keterlambatan dalam mengetahui penyakit kanker yang diderita. ${ }^{16}$

Kondisi perekonomian Indonesia juga bisa menjadi penyebab banyaknya kanker yang ditemukan pada stage akhir. Kemiskinan dan kurangnya sarana prasarana di daerah pedesaan, mengakibatkan banyak warga yang tidak melakukan pemeriksaan kesehatan secara berkala. Jauhnya rumah sakit rujukan utama pun menjadi salah satu alasan utama sulitnya masyarakat untuk memeriksakan diri. ${ }^{16}$

\section{Skala Nyeri}

Hasil penelitian mendapatkan bahwa skala nyeri terbanyak yang dirasakan oleh pasien adalah nyeri sedang. Nyeri yang dirasakan tiap orang berbeda tergantung ambang nyeri yang dimiliki. Seseorang yang tidak atau sedikit memberikan reaksi pada suatu rangsangan nyeri dikatakan memiliki batas ambang nyeri yang tinggi. Sedangkan seseorang yang memberikan reaksi berlebihan terhadap rangsangan nyeri yang sama dikatakan memiliki batas ambang nyeri yang rendah. Jika suatu rangsangan nyeri telah melewati batasan ambang nyeri, maka seseorang akan merasakan nyeri yang berat. Pada hasil yang ditemukan banyaknya nyeri sedang, bisa dikatakan bahwa rangsangan nyeri yang diterima oleh pasien masih berada pada batasan ambang nyerinya. ${ }^{17}$

Data nyeri yang didapatkan pada rekam medik adalah data awal ketika pasien datang untuk melakukan pemeriksaan. Data tentang pengobatan pasien sebelum melakukan pemeriksaan tidak terdapat di rekam medik. Pasien mungkin telah melakukan pengobatan sebelumnya terhadap gejala nyeri yang dialaminya. Hal tersebut dapat menjadi bias penilaian hasil skala nyeri pada penelitian ini.

\section{Hubungan Staging Kanker Paru dengan Skala Nyeri}

Hasil penelitian menunjukkan tidak ada hubungan yang bermakna antara staging kanker paru dengan skala nyeri.Nyeri yang ada pada pasien kanker 
dipengaruhi oleh beberapa hal, salah satunya adalah usia. Usia dewasa akhir (36-45 tahun), batasan ambang nyeri yang dimiliki lebih tinggi daripada dewasa awal (26-35 tahun) sehingga pada dewasa akhir nyeri yang dirasakan lebih ringan dibanding dewasa awal. Pada pasien lansia, terdapat mekanisme yang berbeda dalam merespon nyeri. Lansia memiliki metabolisme yang lebih lambat dan rasio lemak tubuh terhadap massa otot lebih besar dibanding usia dewasa, oleh karenanya analgesik dosis kecil mungkin cukup untuk menghilangkan nyeri pada lansia. Penggunaan analgesik dosis kecil ini umumnya untuk menghilangkan atau mengurangi nyeri ringan dan sedang. ${ }^{18}$

Faktor lain yang juga cukup mempengaruhi nyeri yang dialami pasien adalah kondisi psikologis. Banyak pasien yang tidak menerima kondisi yang dialaminya. Didiagnosis kanker merupakan kondisi berat yang dapat mengganggu psikologis seseorang. Pasien yang tidak bisa menerima keadaan, cenderung menginterpretasikan nyeri yang dialaminya sebagai suatu hal yang besar. Nyeri ringan yang biasa dirasakan pun, dapat diinterpretasikan sebagai nyeri berat. Pada pasien yang telah menerima keadaan yang dialaminya kebanyakan merasakan nyeri pada tingkatan sedang atau ringan. Meskipun tidak banyak penelitian mengenai hubungan kondisi psikologis terhadap nyeri pada pasien, tetap ada beberapa penelitian yang menemukan hubungan bermaka diantara keduanya. Pada penelitian ini kondisi psikologis tidak diteliti, sehingga diperlukan penelitian lebih lanjut untuk mengetahui pengaruhnya terhadap nyeri. $^{17}$

Banyak faktor yang mempengaruhi nyeri yang dialami pasien. Faktor tersebut antara lain usia, jenis kelamin, lingkungan, psikologis dan pekerjaan. Banyaknya hal yang mempengaruhi nyeri membuat hubungan stage kanker paru tidak memiliki hubungan yang bermakna terhadap skala nyeri yang dialami oleh pasien. Hubungan yang bermakna mungkin bisa didapatkan jika berbagai faktor yang mempengaruhi nyeri juga ikut diteliti.

\section{SIMPULAN}

Tidak ada hubungan yang bermakna antara staging kanker paru dengan skala nyeri yang dialami oleh pasien kanker paru yang dirawat di bagian paru RSUP DR M Djamil Padang.

\section{DAFTAR PUSTAKA}

1. GLOBOCAN 2012: Estimated Cancer Insidence, Mortality and Prevalence Worldwide in 2012 (diunduh 29 Agustus 2017. Tersedia dari: http://globocan.iarc.fr/Pages/fact sheets cancer.as px?cancer=lung

2. McWilliam A, Mayo J, MacDonald S, leRiche JC, Palcic B, Szabo E, et al. Lung cancer screening. American Journal of Respiratory and Critical Care Medicine. 2003;168:1167.

3. Siegel R, Ma J, Zou Z, Jemal A. Cancer statistics 2014. CA: A Cancer Journal for Clinicians. 2014;64:9-29.

4. Pusat Data dan Informasi Kementrian Kesehatan RI. Stop Kanker. Jakarta Selatan: Kementrian Kesehatan RI; 2015.

5. Ellis PM, Vandermeer R. Delays in the diagnosis of lung cancer. Journal of Thoracic Disease. 2011;3(3):183-8.

6. Wysham NG, Cox CE, Wolf SP, Kamal AH. Symptom burden of chronic lung disease compared with lung cancer at time of referral for palliative care consultation. AnnalsATS. 2015;12(9):1294-9.

7. Kuchuk M, Kuchuk I, Sabri E, Hutton B, Clemons $\mathrm{M}$, Price PW. The incidence and clinical impact of bone metastases in non-small cell lung cancer. Lung Cancer. 2015;(89):197-202.

8. Rausch SM, Gonzalez BD, Clark MM, Patten C, Felten S, Liu H, et al. SNPs in PTGS2 and LTA Predict Pain and Quality of Life in Long Term Lung Cancer Survivors. Lung cancer. 2012(77):217-23.

9. Zylla D, Kuskowski MA, Gupta K, Gupta P. Assosiasion of opioid requirement and cander pain in advanced non-small cell lung cancer. British Journal of Anaesthesia. 2014; Jul 1;113(Suppl 1):i109-i16. 
10. Alberg AJ, Ford JG, Samet JM. Epidemiology of lung cancer. ACCP evidence-based clinical practice guidelines (2nd edition). 2007;132:29-55.

11. Hulma MA, Basyar M, Mulyani H. Hubungan karakteristik penderita dengan gambaran sitopatologi pada kasus karsinoma paru yang dirawat di RSUP Dr. M Djamil Padang. Jurnal Kesehatan Andalas. 2014;3(2):196-201.

12. Somantri I. Asuhan keperawatan pada pasien dengan gangguan sistem pernafasan. Edisi ke-2. Jakarta: Salemba Medika; 2009.

13. Hertz RP, Margaret MD, Susan WP. The Burden of cancer in Asia. USA: Pfizer; 2008.

14. Maba GKH. Ternyata rokok haram. Surabaya: PT Java Pustaka; 2008.
15. Haryati, Bakhriyansyah M, Aisah SKN. Profil penderita kanker paru primer di rumah sakit umum daerah Ulin Banjarmasin tahun 2006-2011. Jurnal Respirasi Indonesia. 2013;33(1):50-6.

16. Laksmiarti T, Budisuari MA, Ardani I. Pilihan pelayanan kesehatan oleh masyarakat perbatasan negara. Buletin Penelitian Sistem Kesehatan. 2014;17(4):353-62.

17. Raylene MR. Penilaian nyeri. Lyrawati D, penterjemah. AHRQ Publication No. 02-E032. Rockville: Agency for Healthcare Research and Quality; 2002.

18. Smeltzer SC, Bare BG. Buku ajar keperawatan medikal bedah Brunner dan Suddart Vol 3. Edisi ke-8. Jakarta: EGC; 2002. 